\title{
72-Necib Mahfûz’un “Evlâdu Hâratinâ” adlı romanının Türkçe ve İngilizce çevirilerinin karşılaştırılması
}

\section{Ercan BARAN1}

APA: Baran, E. (2022). Necib Mahfûz’un "Evlâdu Hâratinâ" adlı romanının Türkçe ve İngilizce çevirilerinin karşılaştırılması. RumeliDE Dil ve Edebiyat Araştırmaları Dergisi, (26), 1141-1154. DOI: $10.29000 /$ rumelide.1074099.

\section{Öz}

Necip Mahfûz, Mısırlı olup tüm dünyaca tanınan ünlü bir roman yazarıdır. Yazarın dünyaca tanınır olmasında hiç şüphesiz 1988 de Nobel Edebiyat ödülünü almasının büyük payı vardır. Yazar anlatılarında toplumsal sorunları ele almakla kalmayı, ülkenin siyasal sorunlarıyla da ilgili olarak mesajlarını sembolik romanlarıyla vermeye çalışmıştır. Yazar kendi ülkesindeki Cemal Abdunnasır ve benzeri tiranlar için özellikle sembolik romanı Evlâdu Hâratinâ'yı yazmıştır. Yazar bu romanını öncelikle günlük olarak yayınlanan el-Ehram gazetesinde 1959 yllında neşretmiş ve bu roman sebebiyle bazı sıkıntılar yaşamıştır. Yazarın romanının Mısır'da basılamayacağına dair resmi bir yasak olmamasına rağmen romanının basımı yazarın ölümünün hemen ardından Mısır'da 2006 yılında yapılmıştır. Evlâdu Hâratinâ adlı sembolik anlatı Mısır'da ki diktatör Cemal Abdunnasır ve gibilerini eleştirirken aynı zamanda Sami dinlerin kıssalarının ana çerçevesini oluşturduğu adil bir düzen ve sosyal adalet arayışını romanında bize anlatmaktadır. Müellif bu romanında dinsiz bilimin bizlere felaket getireceğini anlatmak istemektedir. Dünyada yayınlanan sanatsal eserlerin kaynak dilden hedef dile çevirileri önem arz etmekte olup okuyucunun sanatsal anlatıları okurken zevk alması önem arz etmektedir. Bu da çeviriyi ve çeviride eşdeğerliliği önemli hale getirip çeviri stratejilerinin önemini artırmaktadır. Çeviriyi yapan çevirmenin kaynak dile hâkim olduğu kadar hedef dile de hâkim olması çeviriden okuma yaparken alınan okuma hazzını artıracaktır. Bu makalede Evlâdu Hâratinâ adlı roman ara dil İngilizceden ve Arapçadan olmak üzere iki Türkçe çevirisi ile Kahire'deki Amerikan Üniversitesinin yaptığı İngilizce dâhil üç çevirisi eşdeğerlilik kapsamında karşılaştırılıp olup farklı çeviri stratejileri açısından da değerlendirilmiştir.

Anahtar kelimeler: Necib Mahfûz, Cemal Abdunnasır, Evlâdu Hâratinâ, çeviri stratejileri, eşdeğerlilik

\section{Comparison of Turkish and English translations of Naguib Mahfouz's novel "Evladu Haratina"}

\begin{abstract}
Nagurb Mahfoûz, is a famous Egyptian novelist who is known all over the world. Undoubtedly, the fact that he was awarded the Nobel Prize for Literature in 1988 played a major role in the author's world-renown. The author not only deals with social problems in his narratives, but also tries to give his messages about the political problems of the country with his symbolic novels. The author first published this novel in the daily al-Ehram newspaper in 1959 and experienced some difficulties due to this novel. Although there is no official ban that the author's novel cannot be published in Egypt, the publication of his novel took place in Egypt in 2006, right after the author's death. While the
\end{abstract}

Dr., Ankara Yıldırım Beyazıt Üniversitesi, Arap Dili ve Belagati (Ankara, Türkiye), ercanbaran773@gmail.com, ORCID ID: 0000-0002-9604-0300 [Araştırma makalesi, Makale kayıt tarihi: 24.01.2022-kabul tarihi: 20.02.2022; DOI: 10.29000/rumelide.1074099]

RumeliDE Dil ve Edebiyat Araştırmaları Dergisi Osmanağa Mahallesi, Mürver Çiçeği Sokak, No:14/8 Kadıköy - İSTANBUL / TÜRKIYE 34714 tel: $+905057958124,+902167730616$
Address

RumeliDE Journal of Language and Literature Studies

Osmanağa Mahallesi, Mürver Çiçeği Sokak, No:14/8

Kadıköy - ISTANBUL / TURKEY 34714

e-mail: editor@rumelide.com,

phone: +90 $5057958124,+902167730616$ 
symbolic narrative Evlâdu Haratinâ criticizes the dictator Jamal Abdunnasir and others in Egypt, it also tells us in his novel the search for a just order and social justice, which is the main frame of the stories of Semitic religions. In this novel, the author wants to explain that irreligious science will bring disaster to us. In this article, the novel Evlâdu Haratinâ is compared in terms of equivalence and evaluated in terms of different translation strategies, with two Turkish translations from the intermediate language English and Arabic, and three translations made by the American University in Cairo, including English.

Keywords: Naguıb Mahfoûz, Jamal Abdunnasir, Evlâdu Haratinâ, translation strategies, equivalence

\section{Giriş}

Yazar, Mısır'da ve Arap dünyasında öncü romancılardan kabul edilmektedir. Yazar antiemperyalist tarihi üç romanına ek olarak toplumsal sorunları ele alan eleştirel romanlarıyla da mesajlarını topluma sembolik kurgu yoluyla iletmeyi başarmıştır.

1911'de Kahire'de Cemâliyye semtinde dünyaya gelen (Baran, 2015:18) yazar Kahire'de ki Abbâsiye semtine taşınıp ilk ve orta öğrenimini orada tamamlar. (Ğitani, 1980:13). Abbâsiye zengin, fakir her kesimden insanın yaşadığı (Ğitani, 1980:10) Ramazan ayında toplumun bütün kesimlerin bir araya gelip kaynaştığı bir yerdi. Mısır dışından Kahire’ye gelenler de Abbâsiyye'de tekkeler de misafir edilirdi. Mısır'da ki bu tekkeler yazarın kurgularında kendilerine yer bulur (Ğitani, 1980:11).

Yazarın babası siyaseti seven biri olarak Mısır'ın önde gelen siyasi figürlerinden Mustafa Kâmil, Sa'd Zaglûl ve Muhammed Ferid’i överdi. Müellif, üçlemesinde Muhammed Abdulcevad figürüyle babasını tasvir eder. Yazarın babası memurluğu bırakıp ticarete atılmıştır. 65 yaşında (Nakkaş, 1997:19) ölen babasının Kur'an okumasından (Nakkaş, 1997:13), içki ve kumar oynamamasından (Ğitani, 1980:15) evde dinin önemsendiği anlaşılmaktadır (Nakkaş, 1997:13; Ğitani, 1980:14). Yazar Hikâyâtu Hâratinâ (Sokağımızın Hikâyeleri) romanında çocukluk günlerini kurgulamıştır (Ğitani: 1980:13). Yazarın babası 1937 yılında ölür (Ğitani: 1980:15).

Edebiyat eleştirmenleri, yazar’ın kutsallarla ilgili düşünceleri ve kurgularına yansımaları üzerine yorumlar ileri sürmüşlerdir. Mahfûz'un din adamları konusundaki tavrı önemlidir. Yazar, kutsal aylardan olan Ramazan da Hüseyniye'ye sesi güzel din adamlarından olan Şeyh Ali Mahmud'u dinlemeye gider ve orada arkadaşlarıyla otururdu. Öyleki sabahın geç saatlerinde bile yazarı kutsal yerlerde görmek mümkündü(Abdu'l-Aziz, 2006:34; Ğitani, 1980:19,21). Yazar güzel Kur'an okuyan Abdussamed'i (1927-1988) dinlediği gibi kutsalları ve kutsal adamları ayrı değerlendirirdi (Abdu'l-Aziz, 2006:29). Müellif'in peygamber efendimizin torunu Hz. Hüseyin'e önem verip her daim onun makamına gereken değeri vermiştir. Bu da onun kutsallara ve kutsalların sembollerine verdiği değeri göstermesi açasından önem arz etmektedir (Abdu'l-Aziz, 2006:40).

Yazar yirmi beşinde üniversite okuyacağı bölümle ilgili olarak karar vermede çelişkiye düşmüş olup, edebiyat mı yoksa felsefe mi okumalıyım diye düşünüp en sonunda edebiyat okumaya karar verir ve 1936 yılında üniversiteye başlar (Abd'u'l-Aziz, 2006:37,41). Müellif eserlerini yayınlamak istediğinde hiçbir yayınevi yayınlamak istemez. Devreye o devrin tanınan simalarından Abdulhamit Cûde es-Sahhâr girer ve yazardan kısa hikâye yazmasını ister. Kahire Üçlemesi romanlarını ilk başta bir kitapta bastırmak isteyen yazara es-Sahhâr üç ayrı kitap olarak bastırmasını tavsiye eder. Yazar'ın üçlemesi de

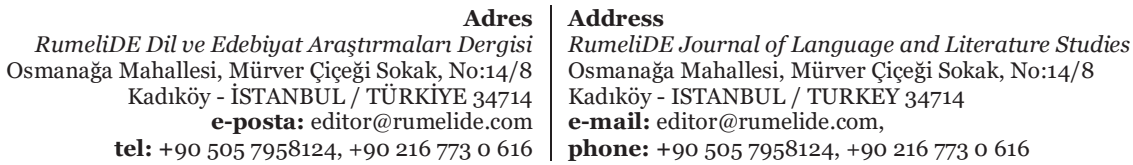


böylece ortaya çıkmıştır (Mahfûz, 1988:294). Onun ilk hikâye seçkisini dahi es-Sahhâr yapmıştır (Ğitani, 1980:38).

Müsellifin yabancı bir yazar olan James Bayki'ye ait olan bir eseri İngilizceden Arapçaya çevirir (Ğitani, 1980:39). Yazar tasavvufun önde gelen şairlerinden olan İranlı Hâfız Şirâzî̀den etkilenir ve bu duygularını bir tekke romanı olan Harafish Destanı (Mahfûz, 2013) adlı anlatısında tasvir eder (Ğitani, 1980:42).

Yazar Arap Edebiyatının ilk dönemlerine ait kanon eserleri okumadığı gibi Felsefe ve Edebiyat arasındaki sorunları ele alan eserler yazmak ister. Yazar İngilizlere karşı bir antiemperyalist tavır oluşturmak amacıyla Firavun medeniyetindeki direnişi öven tarihi romanlar yazar (Ğitani, 1980:43). Müellif in ilk dönem olan Firavunlarla alakalı anlatılar kurgulaması, Selâme Musa’nın yazarı etkilediğini göstermektedir (Mahfûz, 1996:11). Yazarın üniversiteden hocası olan Şeyh Mustafa Abdurrezzâk, yazarı tarihi kurgulara olan ilgisi dolayısıyla Corci Zeydan arasında paralellik kurar. Yazar Firavunlar dönemi ne ait üç tarihi direniş romanı yazar. Yazar, İngilizlere karşı bir direniş edebiyatı geliştirilmesi gerektiğini düşünüp Firavun hanedanlarına ait dönemi anlatılarında kullanır. Müellif, üç tarihi anlatısını antiemperyalist bir çizgide İngilizlere karşı yazarak anlatılarında bu tür yönetimlerden kurtulmak istediğini ifade eder (Ğitani, 1980:44).

1919 Devrimi ve 1952 Darbesi yazar açısından anlamlı olup yazar bu devrimlere başlangıçta olumlu yaklaşsa da 1952 darbesine bakışı zamanla değişmiştir. Yazar, 1967 yılında yapılan Arap İsrail savaşında alınan yenilgiye de çok üzülmüştür (Ğitani, 1980:54). Müellif, siyaseti sevmesine rağmen siyasete atılmamıştır (Nakkaş, 1995:21). Müellif, Sa'd Zaglul'u siyasetçi olarak çok sevdiğini ama onu göremediği için üzüldüğünü ifade etmektedir (Abdu'l-Aziz, 2006:294).

Yazar Mısır’n önde gelen gazetesi olan el-Ehram'da 1959 yllında Evlâdu Hâratinâ adlı anlatısını günlük olarak tefrika eder ve çeşitli sorunlar yaşar. Yazarın ülkesinde resmi bir yasak olmasa da romanı yayınlanamaz. Ta ki ölüm tarihi olan 2006 yllına kadar. Süheyl İdris 1967 yllında Lübnan Beyrutta Dâru'l-Adâb yayınevi adına bu romanı basar (Nakkaş, 1995:160; Ğitani, 2007:20)

Nobel ödülünü 1988 tarihinde alan (Nakkaş, 1997:68; Er, 2012:157; Nakkaş, 1995:31; Ğitani, 2007:5) Mahfûz, "İsrail’i güçle durduramıyorsak başka bir çözüm bulmalıyız" diye konuşur. (Nakkaş, 1997:27) İnsanlar Mahfûz’un haksız yere Nobel edebiyat ödülü aldığını söyleyerek eleştirirler. Bu eleştirilerine de İsrail'i desteklemesini gösterirler (Keşk, 1979:227) Yazar kendisini haksız yere eleştirenlere şunu söyler: : "yaptzklarımdan sorumluyum belik söylediklerimde hata yapmış olabilirim ama ihanet ettiğimi söyleyen yalan söyler ne yaptıysam ülkem adına yaptım.” (Abdu'l-Aziz, 2006:176). Romantik Cibrân gibi bazı edebiyatçlar yazarın böyle bir ödülü alabileceğini vurgular (elHamisi, 2011:16).

Şeyh Ömer Abdurrahman gibi önde gelen selefi şeyhlerin fetvalarından dolayı 1994’te (Nakkaş, 1995:8) bu fetvadan etkilenen bir genç yazara suikast düzenler (Ğitani, 2007:20) ve yazarın sağ eli felç olur (Ğitani, 2007:15). Yazar 2006 yllında 95 ylllık ömrünü tamamlayarak Kahire'de vefat eder (Mahfûz, 2015:1).

\section{1. Çeviride eșdeğerlilik}

Evlâdu Hâratinâ (Mahallemizin Çocukları) romanına ait eşdeğerlilikle ilgili değerlendirmelerden önce çeviride eşdeğerlilik ve eşdeğersizlik konusuna değinilecektir.

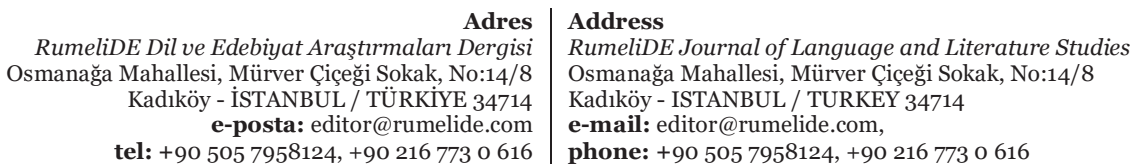


İnsan hayatında farklı alanlar olduğu gibi bu alanlara ilişkin çevirilerde farklllık göstermektedir. Çeviri, edebiyata, kutsallara görsel sanatlardan olan sinemaya kadar çeşitlilik göstermektedir. Çeviri estetiksel haz açısından da önemlidir. Çeviri sadece kendi içerisinde kaynak dilden erek dile çeviri işi değil kaynak dildeki bütün ögeleri olduğu gibi erek dile de aktarmadır. Her kültürde farklılıklar olduğu içinde bazen çeviri yapmak zorlaşmaktadır. İşte burada da çeviri stratejileri devreye girmektedir (Aksoy, 2002:7).

Çeviride iki yaklaşım söz konusudur. Çeviri yapılırken yerelleştirme ve yabancılaştırma söz konusu olabilir. Bu durumda okuru olumlu veya olumsuz etkileyebilir (Snell-Hornby, 2006:10). Çeviri yapılacak metin öteki dile çevrildiğinde artık çevirmenin izlerini taşımaktadır. (Göktürk, 2016:104,105).

Tercüme yapılırken önemli olan eşdeğerliliği hey yönden sağlayabilmektir (Aktaş, 1996:94). Çeviride asıl olan biçimsel eşdeğerlik uyumu sonra anlam uyumudur (Nida ve Taber, 1982:24). İki dilde var olmak için okur kitlesi göz ardı edilmemelidir (Newmark, 1988:83). Bununla birlikte, tercümanların farklı bir dilde yazılmış kaynak bir eserin içeriğini değiştirmeden hedef metne çevirmeleri çeviri için oldukça önemli bir husustur (Bölükbaşı, 2020:2875).

\section{2.Çeviriye dair stratejiler}

İki dilli çeviride bazı stratejilerin gözetilmesi gerekir. (Yıldız, 2019:242, 243). Yeteri derecede düzgün bir çeviri ortaya konamazsa stratejiler devreye girmelidir (Suçin, 2013:30). Çevirmenin iki dile hâkim olması okuyucuda estetiksel hazzı artırır (el-Cahız, 2003:137). Dolayısıyla, mütercimler kendi yorumlarını çevirilere katmışlardır (Bölükbaşı, 2021: 562).

Eşdeğersizliği azaltmak için çevirmenler şu stratejilere başvurabilir (Munday, 2001:56-59; Kurt, 2019:52).

1. Ödünç alma: Asıl metinden öteki dile ögelerin aynen aktarılmasıdır (Yazıcı, 2011:65).

2. Öykünme: Asıl metindeki ögenin öteki dile birebir aktarılmasıdır.

3. Birebir çeviri: Asıl metni öteki dile biçimsel anlamda olduğu gibi aktarmaktır.

4. Yer Değiştirme: Bu yöntemde kaynak dildeki öğeler anlamı değişmeden hedef dile aktarılır.

5. Dönüştürüm / Değiştirme: Asıl metindeki anlam diğer dile aktarllırken değişebilir (Berk, 2005: 138). Bu bağlamda; Arap-İslam dünyasının farklı ilim alanlarında ilerlemesinde önemli katkısı olan Beytu'lHikme'de, görev yapan mütercimler tercüme ettikleri eserleri günümüze yakın bir anlayışla Arapçaya aktarmışlardır. Çünkü tercümelerini kelime kelime yapmak yerine metinlerde geçen eksik ve yanlış bilgileri düzelterek Arapçaya aktarmışlardır (Bölükbaşı, 2021:27).

6. Eşdeğerlik Düzeyi: Asıl metindeki ifadenin erek metne aktarılırken deyim ve atasözlerinin de kullanılmasıdır (Doğru, 2011:73).

7. Uyarlama: Asıl metni öteki dile çevirirken eşdeğerliliğin sağlanamadı̆̆ı eşdeğersizlik durumlarında uyarlama yapılır (Berk, 2005:57). Tercümede, bir durumun veya anlamın bir dilden başka bir dile aktarılması söz konusudur. Teknik anlamda "tercüme faaliyetleri" medeniyetlerin ve kültürlerin birbirleriyle karşılaşıp etkileşim kurmaları sırasında, belli bir birikime sahip eserlerin karşlıklı olarak nakledilmesidir (Bölükbaşı, 2020:1007).

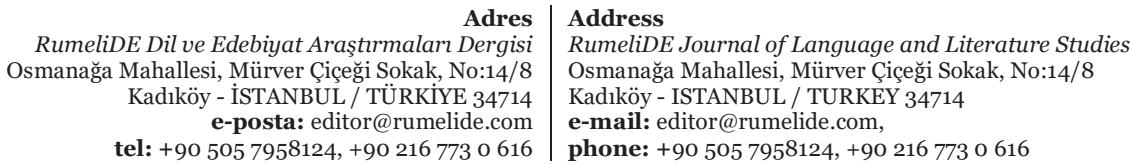


Newmark, (1988) çeviri stratejilerini şu şekilde sıralamıştır:

1.Aktarım: Asıl metindeki ögenin öteki dile doğru bir şekilde aktarılmasıdır.

2.Yerlileştirme: Kaynak metin erek metne aktarılırken asıl dil ve erek dil dikkate alınır.

3.Kültürel eşdeğerlik: Asıl dildeki kültürel ögelerin öteki dilde de karşıllğının bulunmaya çalışılmasıdır. 4.İşlevsel eşdeğerlik: Asıl dildeki ögenin erek dilde karşılığının bulunmaya çalışılmasıdır.

5.Betimleyici eşdeğerlik: Asıl dildeki ögenin öteki dilde birden fazla kelime ile açıklanmasıdır.

6.Çok bileşenli tahlil: Asıl metindeki kelimelerin öteki dilde karşıllı̆ının bulunamaması durumunda ek sözcük bulmaktır.

7.Eş anlamlılık: Kaynak dili erek dilde birebir biçimsel ve anlamsal anlamda çevirmeye çalışıp eşdeğersizliği yok etmektir.

8.Öykünme/ alıntılama: Asıl metindeki dil bilgisel ögelerin öteki dilde birebir karşılanmasıyla çevrilmesidir.

9.Yer değiştirme: Asıl metindeki dil bilgisel ögelerin öteki dilde de yerlerinin değiştirilerek karşıllklarının verilmesidir.

10.Düzenleme: Asıl metnin anlaşılamaması ya da eşdeğersizliğin olduğu durumlarda öteki dilde yeni düzenleme yapılmasıdır.

11.Makul standart çeviri yapma: Kaynak dildeki ögelerin karşlıklarının bulunamaması durumunda erek dilde makul düzeyde karşllı̆̆ının bulunmaya çalışılmasıdır.

12.Ödünleme/ telafi: Asıl dildeki ögenin sembolik olması durumunda öteki dilde farklı karşılıklarla bunu ifade etmeye çalışmadır.

13.Redaksiyon ve genişletme: Assl metindeki zayıf bir ifadenin öteki dilde güçlü bir şeklide ifade edilmesidir.

14.Açımlama: Asıl dildeki ögenin erek metinde anlaşılamaması durumunda kelime ilave ederek açılamadır.

15.Çift süreç kullanımı: Asıl dildeki ögenin birkaç stratejiyle çevrilmesidir.

16.Notlar, eklemeler, açıklamalar: Kaynak metnin öteki dilde anlaşılması adına açılamalar eklemedir.

17.Çıkarma: Asıl dildeki bir kelimenin öteki dile aktarılırken çevirmence yazılmamasıdır (Newmark, 2010: 81-93)

Stratejiler konusunda farklı görüşler bulunmakta olup stratejilerde değişmektedir. Bu stratejistlerden biri olan Baker çeviride eşdeğerliliği şöyle verir (Baker, 2011: 23-47).

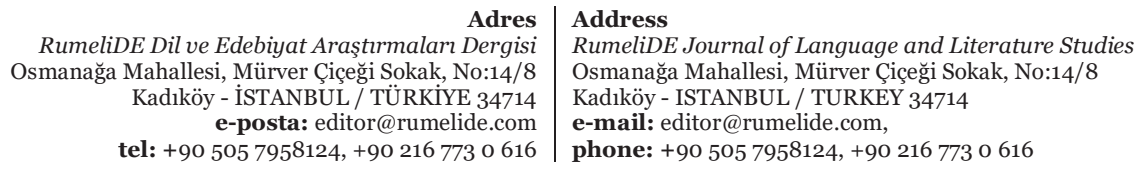


1. Genelleştirme - Üst Anlamlı: Asıl metinde yer alan bir ögenin öteki dile daha geniş anlamlı olarak ifade edilmesidir.

2. Özelleştirme - Alt Anlamlı: Asıl metinde yer alan bir ögenin öteki dile daha dar anlamlı olarak ifade edilmesidir (Dickins, 2017:77)

3. Kültürel İkame: Dillerde farklılıkların olması ve kültürel farklılıklar dikkate alındığında asıl dildeki kelimenin erek dilde karşıllı̆̆ının bulunmaya çalışılmasıdır.

4. Kültürel Ödünçleme: Asıl dildeki bir ögenin olduğu gibi öteki dile aktarılmasıdır.

5. Açımlama: Asıl dildeki bir dil bilgisel ögenin öteki dilde dil bilgisel karşılıklarının bulunmaya çalışılmasıdır.

6. Çıkarma: Asıl dildeki ögelerin bazı kısımlarının öteki dilde çıkarılmasıdır.

7. Açıllama: Asıl dildeki bir ögenin öteki dilde karşılığı yoksa açıklama yaparak ya da dipnot vererek anlatma yoluna gidilir (Aksan, 2015:76).

Venuti çeviri stratejilerinin birbirlerine benzediğini ifade eder (Venuti, 2004:20-21).

\section{Yapılan dört çeviride eşdeğerlilik ve eşdeğersizlik}

Kaynak dilden Şuruk yayınevinin baskısı, Kahirede'ki Amerika Üniversitesinin kaynak dilden erek dile yaptığı İngilizce çeviri, Leyla Basmacı Tonguç’un ara dil İngilizceden Türkçe’ye yaptığı çeviri ve Ercan Baran'ın kaynak dilden öteki dil olan Türkçeye çevirisi değerlendirilecektir. Çeviriler şu sıraya göre değerlendirilmiştir.

1.Necip Mahfûz, Evlâdu Hâratinâ, Dâru'ş Şurûk, 9. Baskı, Kahire 2011.

2.Naguib Mahfouz, Children of The Alley, The American Unıversity In Cairo Press, Kahire 2001. (Arapçadan Çeviri)

3.Necip Mahfûz, Cebelavi Sokağının Çocukları, Çev. Leyla Tonguç Basmacı, 4. Baskı, İstanbul 2012. (Ara dil Avrupa İngilizcesinden Çeviri)

4.Ercan Baran Evlâdu Hâratinâ, (Arapçadan Çeviri)

\section{4. Çeviri karşılaștırma örnekleri}

Tablo 1

\begin{tabular}{|c|c|c|}
\hline Şuruk & & رفاعة عرفة (s.5) \\
\hline $\begin{array}{l}\text { Amerikan } \\
\text { Üniversitesi }\end{array}$ & \multicolumn{2}{|l|}{ Rıfaa; Arafa (s. Giriş) } \\
\hline $\begin{array}{l}\text { Leyla Basmacı } \\
\text { Tonguç }\end{array}$ & \multicolumn{2}{|c|}{$\begin{array}{l}\text { Kitabın giriş kısımdaki içindekiler ve içerisindeki yazılı olan isimler olmadığı gibi kitap } \\
\text { içerisinde de bazı isimler yanlış yazılmıştır. Rıfâ'a Rıfat; Arefe Arif şeklinde yazılmış. } \\
(\mathrm{s.175}, 365)\end{array}$} \\
\hline Ercan Baran & \multicolumn{2}{|l|}{ Rıfâ'a; Arefe (s.5) } \\
\hline & $\begin{array}{r}\text { Adres } \\
\text { E Dil ve Edebiyat Araşttrmaları Dergisi } \\
\text { Mahallesi, Mürver Çiçeği Sokak, No:14/8 } \\
\text { Kadıköy - İSTANBUL / TÜRKIYE } 34714 \\
\text { e-posta: editor@rumelide.com } \\
\text { el: +90 } 5057958124,+90216773 \text { o } 616\end{array}$ & $\begin{array}{l}\text { Address } \\
\text { RumeliDE Journal of Language and Literature Studies } \\
\text { Osmanağa Mahallesi, Mürver Çiçeği Sokak, No:14/8 } \\
\text { Kadıköy - ISTANBUL / TURKEY } 34714 \\
\text { e-mail: editor@rumelide.com, } \\
\text { phone: +90 505 7958124, +90 } 216773 \text { o } 616\end{array}$ \\
\hline
\end{tabular}


Romanın Türkiye'de Cebelavi Sokağının Çocukları adıyla yapılan 14. baskısında Leyla Basma Tonguç'un yaptığı çeviride kitabın asıl adı Awlad haratina olarak geçerken; 1. Basımı 2010 yılında yapılan romanın çevirisinde kitabın asıl adı Asr al-Hubb olarak birebir şu şekilde yazılmıştır:

"Bu kitap Arapçada ilk kez Asr al-Hubb adıyla basılmıştır. Bu çeviri The American University in Cairo Press aracılığıyla çevrilmiştir” diye yazılıdır. Hâlbuki Kahire Amerikan Üniversitesi Mahfûz’un kitabını İngilizceye Chıldren of The Alley olarak çevirmiştir ve kitabın baş sayfasında Arapçası olarak da şöyle yazılıdır:

"First published in Arabic in 1959 as Awlad haratina" bu cümleden anladığımız Kırmızı Kedi adına çeviren Leyla Basmacı Tonguç İngilizce kısmına bakmamış ve dikkat etmemiş olduğudur. Tonguçun Kahire İngilizcesini bile dikkate alsa bu isimleri doğru yazacağını düşünmekteyiz. Ama Kırmızı kedi yayınevinin yayın haklarını Kahire Amerikan Üniversitesinden almasına rağmen çevirmen Leyla Basmacı Tonguç Avrupa baskısını önceleyip bu baskıdan çeviri yapmıştır. Çünkü kitabı Cebelavi Sokağının Çocukları diye Türkçeye çevirmiştir. Oysa Kahire Amerikan İngilizcesindeki çevirinin karşılığı Sokağımızın Çocuklarıdır. Çevirmen burada biçimsel eş değerliliği ihmal ettiği gibi isimlerinin sembolik olmasından dolayı anlam kaybına uğradığından dinamiksel eşdeğerliliği de ihmal edip uygun bir çeviri yapmayarak eşdeğerlilik stratejilerini ihmal etmiş ve asıl/erek metne sadık kalmamıştır.

Yapılan çeviriler içerisinde sadece Leyla Basmacı Tonguç'un yanlış çeviri yaptığını diğer çevirilerin istenen eşdeğerlilĭgi sağlayamayıp ekleme yaptığını görüyoruz. Kahire Amerikan Üniversitesinin yaptı̆̆ birebir çeviri eşdeğerlilikle uygulanmaya çalşslmıştır. Ancak Tonguç kaynak metinden hedef metne çevirirken ara metin olan İngilizceden yararlanmış ve bu kısmı da yanlış çevirerek eşdeğersizliği öncelemiştir.

Tablo 2

\begin{tabular}{|l|l|}
\hline Şuruk & \\
\hline $\begin{array}{l}\text { Amerikan } \\
\text { Üniversitesi }\end{array}$ & But this ancestor of ours is a puzzle (s.3) \\
\hline $\begin{array}{l}\text { Leyla Basmacı } \\
\text { Tonguç }\end{array}$ & Ama büyükbabamız gerçekten bir muammadır! (s.5) \\
\hline Ercan Baran & Ama büyükbabamız da tam bir muammadır. (s.7) \\
\hline
\end{tabular}

Şuruk Yayınlarınca 2006 yılında ilk baskısı yapılan çevirinin Arapçasında gerçekten kelimesi ve Kahire'de bulunan Amerikan Üniversitesinin Arapçadan İngilizce'ye yaptığı çeviride gerçekten anlamını veren really bulunmamakta ama anlamına gelen but kelimesi cümleye ekleme yapılmıştır. Leyla Basmacı Tonguç'ta kaynak dilde olmayan gerçekten anlamına gelen really kelimesini eklemiştir. Burada bütün çeviriler, kaynak dildeki anlamı biçimsel ve dinamik eşdeğerlik olarak hedef dile doğru aktarmıştır. 3. Çeviride bu, gerçekten ve tam kelimelerini cümlelere ekleyerek burada dinamik eşdeğerliliği biçimsel eşdeğerliliğe öncelemişlerdir. Kaynak dildeki anlam, hedef dile aktarılırken değiştirebilir. Bu yolla hedef metindeki bakış açısı değiştirilir veya yeniden düzenlenir. Buna çeviri stratejisinde Değiştirme/ Dönüştürüm diyoruz ki bu strateji burada uygulanmıştır.

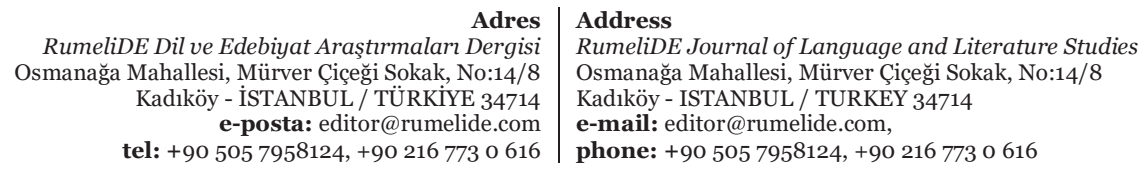


1148 / RumeliDE Journal of Language and Literature Studies 2022.26 (February)

Comparison of Turkish and English translations of Naguib Mahfouz's novel "Evladu Haratina" / E. Baran (pp. 1141-1154)

Tablo 3

\begin{tabular}{|l|l|}
\hline Şuruk & \multicolumn{1}{|c|}{ (s.8) بشروطه العشرة التى كثرالقيل و القال عنها } \\
\hline $\begin{array}{l}\text { Amerikan } \\
\text { Üniversitesi }\end{array}$ & His much-talked-about Ten conditions. (s.4) \\
\hline $\begin{array}{l}\text { Leyla Basmacı } \\
\text { Tonguç }\end{array}$ & Herkesin dilinde olan On Şartı'ydı. (s.6) \\
\hline Ercan Baran & Dedikodusu çokça yapılan On Emir'di. \\
\hline
\end{tabular}

Kaynak dilde بشروطه العشرة her ne kadar on şart olarak geçse de Allah emredeceği için on emir olarak hedef dile çevrilmesi daha isabetli olur diye düşünüyoruz. Aslında burada en başta eleştirilmesi gereken yazarın kendisidir. Dini bir kavramı yani On Emir’i On Şart olarak vermekte hatalıdır denebilir. Çünkü Tevrat, İncil ve Kuran'ı Kerim de şart değil emir olarak verilmiştir. Bu noktada yazar kavramın aslına sadık kalmayarak değiştirme yoluna gitmiştir. Arada nüans farkı vardır denilebilir ama Allah'ın emrettiği düşünülürse bu hassasiyet daha iyi anlaşllabilir düşüncesindeyiz. Kaynak kültürdeki bir ögenin erek dile aynı ögelerle aktarımını ödünçleme yoluyla yaparken yapılan bu çeviride bunun gerçekleşmediğini görüyoruz. Oysaki “Emir” kelimesi Arapçadan Newmark’nn kültürel ödünçleme stratejisi yoluyla alınabilirdi.

Amerikan Üniversitesinin yaptığı çeviride talk yerine gossip fiili kullanılabilirdi. Her ne kadar ikisinde de dedikodu anlamı olsa da talk daha çok konuşmak ama gossip daha çok dedikodu yapmak manasında kullanıldığı için Amerikan Üniversitesinin kaynak dilden hedef dil olan İngilizce'ye yanlış çeviri yaptığını düşünmekteyiz. Amerikan Üniversitesi hem biçimsel ve hem dinamiksel eşdeğerliliği ihmal ederek eşdeğerliliği sağlayamamıştır.

Yazar kelimeyi anlatısında yanlış kullanınca hedef dil İngilizce ve ara dil olan İngilizce'den Türkçe'ye yapılan çeviride dolayısıyla yanlış çevrilmiştir. Leyla Basmacı Tonguç’ta On şart diye çevirmiştir. Dedikodu kelimesini ise herkesin dilinde olan diye çevirmiştir. Tonguç burada Arapça 'da verilen كث ve İngilizce'de verilen much kelimesinin anlamını vermeyerek biçimsel ve dinamiksel eşdeğerliliği ihmal ederek eşdeğerliliği sağlayamamıştır.

Baran’ın ise çevirisinde hem biçimsel hem dinamiksel eşdeğerliliği sağladığını görüyoruz.

Tablo 4

\begin{tabular}{|l|l|}
\hline Şuruk & \\
\hline $\begin{array}{l}\text { Amerikan } \\
\text { Üniversitesi }\end{array}$ & The Benefactor ... (s.9) \\
\hline $\begin{array}{l}\text { Leyla Basmacı } \\
\text { Tonguç }\end{array}$ & Hayırsever adam... (s.11) \\
\hline Ercan Baran & Cebelâvî (s.11) \\
\hline
\end{tabular}

Kaynak dilde vâkıf olarak ifade edilen kelime sembolik olarak kullanılmıştır. Burada vâkıf kelimesinden kasıt hayır dağıtan değil tüm kâinatın ve Mısır’n sahibi Cebelâvî'dir. Kahire'deki Amerikan Üniversitesinin Arapçadan yaptığı çeviride vâkıf kelimesini hayırsever olarak çevirdiğini görüyoruz. Leyla Basmacı Tonguç ise vâkıf kelimesini ara dil olan İngilizceden hayırsever olarak çevirmiştir. Tonguç’un biçimsel içeriği sağlamaya çalışırken dinamiksel eşdeğerliliği ve sembolik anlamı ihmal

Adres $\mid$ Address

RumeliDE Dil ve Edebiyat Araşttrmaları Dergisi $\quad$ RumeliDE Journal of Language and Literature Studies

Osmanağa Mahallesi, Mürver Çiçeği Sokak, No:14/8 $\quad$ Osmanağa Mahallesi, Mürver Çiçeği Sokak, No:14/8

Kadıköy - İSTANBUL / TÜRKIYE 34714 Kadıköy - ISTANBUL / TURKEY 34714

e-posta: editor@rumelide.com e-mail: editor@rumelide.com,

tel: +90 5057958124, +90 2167730616 phone: +90 5057958124, +90 2167730616 
ettiğini görüyoruz. Tonguç, Newmark’’n betimleyici eşdeğerlik stratejisini uygulamaya çalışmış ve sözcüğ̈̈ sözcüğ̈̈ne çeviri yolunu seçmiştir.

Ercan Baran ise; verilen sembolik ifadeyi alarak metinde adı geçenin vâkıf kelimesi olmadığını ve yazarın Cebelâvî kelimesini imlediğini anlatarak çevirir. Baran bu kelime üzerinden açılama yoluna gitmiştir. Burada Baran'ın hem biçimsel hem dinamiksel eşdeğerliliği sağladığını düşünüyoruz. Leyla Basmacı Tonguç Arapça bilmeyip ara dilden çeviri yaptığı için vâkıf kelimesinin metnin içerisinde sembolik olarak kullanıldığını görmemiştir. İşin asıl ilginç tarafı ise Arapçadan İngilizce'ye çeviri yapan ekibin bu kelimeyi açımlayarak yanlış çevirmesidir.

Tablo 5

\begin{tabular}{|l|l|}
\hline Şuruk & \\
\hline $\begin{array}{l}\text { Amerikan } \\
\text { Üniversitesi }\end{array}$ & The chamber door (Kabul salonu) (s.9) \\
\hline $\begin{array}{l}\text { Leyla Basmacı } \\
\text { Tonguç }\end{array}$ & Salonun büyük kapısına (s.11) \\
\hline Ercan Baran & Bahçenin selamlığında² (s.11) \\
\hline
\end{tabular}

Kaynak dilde selamlık İslam ülkelerine ait bir kavram olarak ifade edilirken Kahire'deki Amerikan Üniversitesinin Arapçadan yaptığı çeviride selamlık kelimesini kabul salonu olarak çevirdiğini görüyoruz. Bir ifadenin erek dile aynı ögelerle aktarımını kültürel ödünçleme yoluyla yaparken yapılan bu çeviride bunun gerçekleşmediğini görüyoruz. Leyla Basmacı Tonguç ise selamlık kelimesini ara dil olan İngilizceden salon olarak çevirmiştir. Tonguç’un biçimsel içeriği sağlamaya çalışırken dinamiksel eşdeğerliliği ihmal ettiğini görüyoruz. Ayrıca kaynak dilde yer alan bir kelime erek dile uyarlanarak aktarılabilir. Biz bu stratejiye açımlama diyoruz ki Tonguç bu cümlede bunu yapmıştır. Bir öge eşdeğer bir karşılık olmayınca bunlar dipnot ile verilir ki biz buna açılama diyoruz. Tonguç bu stratejiyi de çevirisinde uygulamamıştır.

Ercan Baran ise; kaynak kültürdeki bir ögeyi erek dile Newmark’n çeviri stratejisine göre aynı ifadeyle aktarıp, kültürel öğeleri aynen alarak kültürel ödünçleme stratejisini uygulamıştır. Burada Baran'ın hem biçimsel hem dinamiksel eşdeğerliliği sağladığını düşünüyoruz. Leyla Basmacı Tonguç Arapça bilmeyip ara dilden çeviri yaptı̆̆ı için selamlık kelimesini atlamıştır. Tonguç Arapça bilse o kelimeyi kültürel ödünçleme yoluyla alırdı diye düşünmek istiyoruz.

Tablo 6

\begin{tabular}{|l|l|}
\hline Şuruk & \\
\hline $\begin{array}{l}\text { Amerikan } \\
\text { Üniversitesi }\end{array}$ & I am your father. (s.10) \\
\hline $\begin{array}{l}\text { Leyla Basmacı } \\
\text { Tonguç }\end{array}$ & Babanım ne de olsa. (s.12) \\
\hline Ercan Baran & Seni dünyaya getiren benim. \\
\hline
\end{tabular}

2 Yapıların erkek toplulukların kullanımına ayrılmış olan bölümüne selamlık adı verilir.

$$
\begin{aligned}
& \begin{array}{r|l}
\text { Adres } & \text { Address } \\
\text { RumeliDE Dil ve Edebiyat Araştırmaları Dergisi } & \text { RumeliDE Journal of Language and Literature Studies }
\end{array}
\end{aligned}
$$

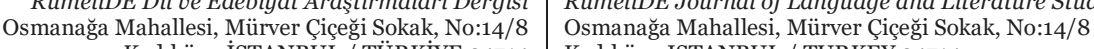

$$
\begin{aligned}
& \text { Kadıköy - İSTANBUL / TÜRKIYY } 34714 \text { Kadıköy - ISTANBUL / TURKEY } 34714 \\
& \text { tel: +90 5057958124, +90 } 2167730616 \text { phone: +90 5057958124, +90 } 2167730616
\end{aligned}
$$


Amerikan Üniversitesi kaynak dil olan Arapçadan hedef dil olan İngilizce’ye yaptı̆̆g çeviride الذي أنجبتأو ilgi zamiri ile başlayan sıfat ortaç olan sıla cümlesini isim tamlaması şeklinde vermiştir. Asıl metinde var olan herhangi bir ibare, hedef dile uyarlanarak aktarılır. Olması gereken yan cümlenin sıfat ortaç ekleri olan an-esi-mez-ar-dik-ecek-miş ekleriyle çevrilmesidir. Amerikan Üniversitesi kaynak dilden hedef dile çeviri yaparken yan cümle yapmayarak biçimsel eşdeğerliliği ihlal ettiği gibi dinamiksel eşdeğerliliği de sağlayamamıştır.

Leyla Basmacı Tonguç ta yan cümle olan sıfat ortaç yani sıla cümlesini ihmal ederek çeviri yaparak çeviri de olması gereken biçimsel eşdeğerliliği ihmal etmiş ve dinamiksel eşdeğerliliği de sağlayamamıştır. Burada vurgulanan babalı değil dünyaya getirenin kim olduğu vurgusu yapılarak vefa duygusunun baba tarafından öncelenmesidir. Bu noktada hem Kahirede'ki Amerikan Üniversitesi hem de Leyla Basmacı Tonguç çeviride eşdeğerliliği sağlayamamıştır. Kahire'de ki Amerikan Üniversitesi ve Leyla Basmacı Tonguç Newmarkın çeviri stratejilerinden olan yer değiştirmeyi çevirilerinde yapmışlardır. Yer değiştirme yönteminde öğeler aynı olarak erek dile aktarılır. Ayrıca kaynak dilde yer alan zarfları, hedef dile fiil şeklinde aktarmak mümkündür. Burada yan cümle olan ilgi zamiri cümlesi farklı aktarılmıştır.

Ercan Baran ise; yan cümle olan sıfat ortaç cümlesini yani sıla cümlesini fiile getirdiği sıfat ortaç eki olan -en eki ile yaparak getiren şeklinde tercüme ederek hem biçimsel hem dinamiksel eşdeğerliliği sağlamıştır. أنجبتك fiilinin burada sıfat ortaç durumuna geçip -en ekini fiile vererek fiillikten çıktığını görüyoruz. Eğer burada literal çeviri yapıp birebir anlamını verirsek -seni doğuran benim-anlamı çıar ki bu yanlış bir çeviri olur. Çünkü bir erkek çocuk doğuramayacağı için dolaylı yolla da olsa kişinin doğmasındaki katkısını belirtmek için Baran -seni dünyaya getiren benim- diye çevirmiştir. Ki bu çeviri hedef dilde anlamı karşılamaktadır.

Tablo 7

\begin{tabular}{|l|l|}
\hline Şuruk & \\
\hline $\begin{array}{l}\text { Amerikan } \\
\text { Üniversitesi }\end{array}$ & Be quiet for your own good, you fool! (Kendi iyiliğin sus ey aptal) (s.11) \\
\hline $\begin{array}{l}\text { Leyla Basmacı } \\
\text { Tonguç لساتك رحمة بنفك يا جاهل }\end{array}$ & Kendi iyiliğin için sus, seni budala. (s.13) \\
\hline Ercan Baran & Kendi iyiliğin için çeneni kapa bre cahil. \\
\hline
\end{tabular}

Amerikan Üniversitesi kaynak dil olan Arapçadan hedef dil olan İngilizce’ye yaptığı çeviride fool yani aptal kelimesi dışında eşdeğerliliği biçimsel ve dinamiksel olarak sağlamıştır. Aptal, bön, budala aşağı yukarı aynı anlamları vermektedir. Leyla Basmacı Tonguç bundan olsa gerek aptal kelimesi yerine budala kelimesini tercih etmeyi yeğlemiştir.

Ercan Baran ise; Asıl kültürdeki bir ifadeyi erek dile kültürel öğeleri ödünç almak suretiyle kültürel ödünçleme ve yerlileştirme stratejisini uygulayarak cahil ve bre kelimelerini Türkçeye aktarmıştır. Yazarın ve insanımızın alışık olduğu bir kelime olan cahil ve bre kelimelerinin tercih edilmesi eşdeğerliliği daha da sağlamlaştırarak okura daha akıcı bir çeviri sunmaktadır. Burada Baran’ın cahil ve bre kelimesini alarak hem biçimsel hem dinamiksel eşdeğerliliği sağlayarak literal çeviriyi ihmal etmediği iletişimsel çeviri stratejisine de uygun davranmıştır.

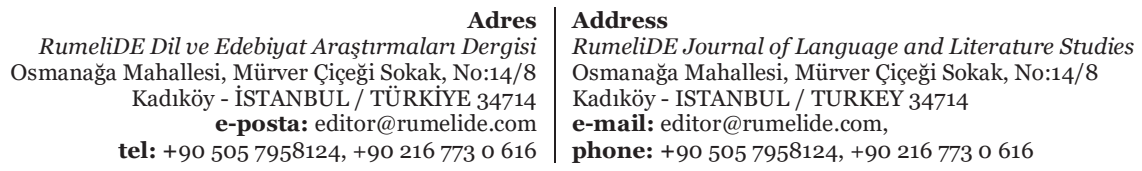


Tablo 8

\begin{tabular}{|l|l|}
\hline Şuruk & \\
\hline $\begin{array}{l}\text { Amerikan } \\
\text { Üniversitesi }\end{array}$ & I hear and obey (s.11) \\
\hline $\begin{array}{l}\text { Leyla Basmacı } \\
\text { Tonguç }\end{array}$ & Söylediklerini duydum ve sana itaat edeceğim. (s.13) \\
\hline Ercan Baran & Baş üstüne!3 \\
\hline
\end{tabular}

طاعة dinlemek itaat etmek olarak anlamını verebiliriz. Ama burada deyimsel bir anlam söz konusudur. Yazar bu deyimsel anlamı bilerek kullanarak anlatımı daha da akıcı hale getirmiştir. Kahire'deki Amerikan Üniversitesi kaynak dil olan Arapçadan hedef dil olan İngilizce'ye çevirirken ben işitirim ve itaat ederim diye çevirmiştir. İngilizce karşılığı için "Yes. Sir." veya "with pleasure" denilebilirdi. Biçimsel ve dinamiksel eşdeğerlilik anlamında bakıldığında bu deyimin İngilizceye aktarılırken eksik aktarıldı̆̆ını eşdeğerliliğin tam sağlanamadığını düşünüyoruz. Leyla Basmacı Tonguç ise ara dil İngilizceden hedef/erek dil Türkçe'ye çevirirken deyimsel bir ifadeyi düz cümle şeklinde aktarmayı tercih ederek biçimsel ve anlamsal eşdeğerliliği sağlayamamış olup eşdeğersizliği öncelemiştir. Bu noktada biz Newmarkın uyarlama ve Venuti'nin yerlileştirme stratejisine katılarak kendi kültürümüzdeki deyimsel ifadelere başvurarak metni daha anlaşlır ve akıcı hale getiriyoruz.

Ercan Baran ise; سمعاً وطاعة bu deyimsel ifadeyi birebir çevirerek Venuti'nin uyarlama ve yerlileştirme stratejisine katılarak kendi kültürümüze akıcı bir şekilde çevirmiştir. Bu anlamda Baran biçimsel eşdeğerliliği atlamadan dinamik eşdeğerliliği daha güzel ifade etme imkânı yakalamıştır. Bu deyim ayetlerde ve filmlerde çokça karşımıza çımmaktadır.

Tablo 9

\begin{tabular}{|l|lc|}
\hline Şuruk & & $\mathbf{1 4}$ \\
\hline $\begin{array}{l}\text { Amerikan } \\
\text { Üniversitesi }\end{array}$ & Yes, Father. (s.11) & \\
\hline $\begin{array}{l}\text { Leyla Basmacı } \\
\text { Tonguç }\end{array}$ & Evet, baba, dedi. (s.13) \\
\hline Ercan Baran & Emrin olur ey babam \\
\hline
\end{tabular}

kelime grubunda deyimsel bir anlam söz konusudur. Yazar bu deyimsel anlamı bilerek kullanarak anlatımı daha da akıı hale getirmiştir. Kahire'deki Amerikan Üniversitesi kaynak dil olan Arapçadan hedef dil olan İngilizce'ye çevirirken evet baba diye çevirmiştir. İngilizce karşllı̆̆ için "Yes. Sir." veya "with pleasure" denilebilirdi. Biçimsel ve dinamiksel eşdeğerlilik anlamında bakıldığında bu deyimin İngilizceye aktarılırken eksik aktarıldığını eşdeğerliliğin tam sağlanamadığını düşünüyoruz. Leyla Basmacı Tonguç ise ara dil İngilizceden hedef/erek dil Türkçe’ye çevirirken deyimsel ifadeyi düz bir cümle şeklinde aktarmayı tercih ederek biçimsel ve anlamsal eşdeğerliliği sağlayamamıştır. Bu noktada biz Venuti'nin yerlileştirme stratejisine katılarak kendi kültürümüzdeki deyimsel ifadelere başvurarak metni daha anlaşılır ve akıcı hale getiriyoruz.

3 Bir isteğin, bir buyruğun yerine getirileceğini belirtmek için “peki”, "peki efendim”, “emredersiniz” gibi kullanılır. Adres Address

RumeliDE Dil ve Edebiyat Arașturmalar Dergisi Osmanağa Mahallesi, Mürver Çiçeği Sokak, No:14/8 Kadıköy - İSTANBUL / TÜRKIYE 34714 e-posta: editor@rumelide.com tel: +90 $5057958124,+902167730616$

RumeliDE Journal of Language and Literature Studies

Osmanağa Mahallesi, Mürver Çiçeği Sokak, No:14/8

Kadıköy - ISTANBUL / TURKEY 34714

e-mail: editor@rumelide.com,

phone: +90 5057958124 , +90 2167730616 
Ercan Baran ise; أمرك يا أبى bu deyimsel ifadeyi birebir çevirerek Newmarkın uyarlama ve Venuti'nin yerlileştirme stratejisine katılarak kendi kültürümüze çevirmiştir. Bu anlamda Baran biçimsel eşdeğerliliği atlamadan dinamik eşdeğerliliği daha güzel ifade etme imkânı yakalamıştır. Bu deyim özellikle savaş filmlerinde çokça karşımıza çıkan bir deyimdir.

Tablo 10

\begin{tabular}{|l|l|}
\hline Şuruk & \\
\hline $\begin{array}{l}\text { Amerikan } \\
\text { Üniversitesi }\end{array}$ & I will obey. (s.11) \\
\hline $\begin{array}{l}\text { Leyla Basmacı } \\
\text { Tonguç }\end{array}$ & İtaat edeceğim. (s.13) \\
\hline Ercan Baran & Siz nasıl uygun görürseniz. \\
\hline
\end{tabular}

kelime grubunda deyimsel bir anlam söz konusudur. Yazar bu deyimsel anlamı bilerek kullanarak anlatımı daha da akıcı hale getirmiştir. Kahire'deki Amerikan Üniversitesi kaynak dil olan Arapçadan hedef dil olan İngilizce'ye çevirirken itaat edeceğim diye çevirmiştir. İngilizce karşıllı̆ı için "Yes. Sir." veya "with pleasure" denilebilirdi. Biçimsel ve dinamiksel eşdeğerlilik anlamında bakıldığında bu deyimin İngilizceye aktarılırken eksik aktarıldığını eşdeğerliliğin tam sağlanamadığını düşünüyoruz. Leyla Basmacı Tonguç ise ara dil İngilizceden hedef/erek dil Türkçe'ye çevirirken deyimsel ifadeyi düz bir cümle şeklinde aktarmayı tercih ederek biçimsel ve anlamsal eşdeğerliliği sağlayamamıştır. Bu noktada biz Venuti'nin yerlileştirme stratejisine katılarak kendi kültürümüzdeki deyimsel ifadelere başvurarak metni daha anlaşılır ve akıcı hale getiriyoruz.

Ercan Baran ise; على العين و الرأس bu deyimsel ifadeyi Türkiye’nin doğusunda kullanılan başımla beraber veya başım gözüm üstüne ifadelerini "Siz nasıl uygun görürseniz" diye birebir çevirmiştir. Newmarkın uyarlama ve Venuti'nin yerlileştirme stratejisine katılarak kendi kültürümüze çevirmiştir. Bu anlamda Baran biçimsel eşdeğerliliği atlamadan dinamik eşdeğerliliği daha güzel ifade etme imkânı yakalamıştır. Bu deyim özellikle savaş filmlerinde çokça karşımıza çıkan bir deyimdir. Leyla Basmacı Tonguç’un yaptığı çeviride eşdeğersizliği öncelediği ve düzgün bir çeviri yapmadı̆̆ı söylenebilir.

\section{Sonuç}

Çeviride eşdeğerlilik kaynak metnin anlamını koruyarak hedef dile aktarma faaliyetidir. Çeviride istenilen başarının elde edilebilmesi için bazı çeviri yöntemlerinin kullanılması gerekir. Ayrıca tercüme işini yapan mütercimin kaynak ve hedef dilin gramer kurallarına vakıf olması çeviride istenilen düzeyde başarı elde edilmesi için oldukça önemli bir husustur. Dolayısıyla, Necip Mahfûz’un üç çevirisi eşdeğerlilik bakımında ele alınmıştır. Evlâdu Hâratinâ romanının 3 farklı çevirisini yapan mütercimlerin çeviri yöntemleri ele alınarak incelenmiştir. Çevirmenler kaynak dildeki kültürel ifadeleri hedef metne çevirirken iletişimsel çeviriyi tercih etmişlerdir. Ayrıca hedef dilde bulamadıkları ifadeleri dipnot veya metin içi açıklamalarla aktarmışlardır. Ancak Leyla Basmacı Tonguç çevirisini ara dil olan İngilizceden yaptığı için roman içerisinde birçok yanlışlıklar barındırmakta olup buda çeviride biçimsel ve dinamiksel eşdeğerliliği bozmaktadır. Ayrıca yazarın kendisi de On Emir gibi kavramsal kullanımlarda On Şart yazımını tercih ederek dinlerdeki orijinalliğe sadık kalmayarak farklı bir kullanım tercih etmiştir. Kaynak dil Arapçadan hedef dil İngilizceye çeviride de çeviri hataları mevcut olup bu hatalar makalede incelenmiştir

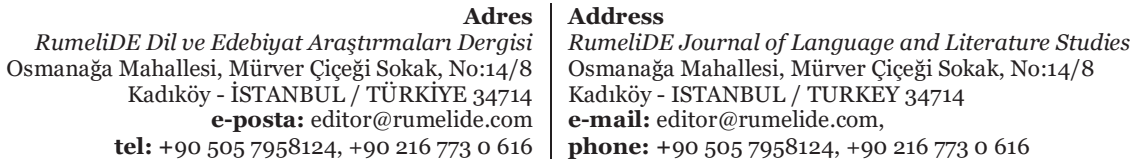




\section{Kaynakça}

Abd'u'l-Aziz, İ. (2006) "Ene Necib Mahfûz Sire Hayâtî Kâmile". Kahire: Munteda Suru'l-Ezbekiyye. Aksan, D. (2015). Her yönüyle dil (6. bs., C. 1-3, C. 1). Ankara: Türk Dil Kurumu Yayınları Aksoy, N. B. (2002). Geçmişten günümüze yazın çevirisi (1. bs.). Ankara: İmge Kitabevi.

Aktaş, T. (1996). Çeviri işlemine genel bir bakış. Ankara: Orsen Matbaacılık.

Baker, M. (2011). In Other Words: A coursebook on translation (2. bs.). USA: Routledge.

Baran, E. (2015) Üç Mısır Romanında Cemal Abdunnâsır Dönemi (el-Kernek, Tilke'r-Râiha, el-Leyâli'tTavîle), Ankara Üniversitesi Sosyal Bilimler Fakültesi Basılmamış Yüksek Lisans Tezi, Ankara.

Berk, Ö. (2005). Kuramlar ışı̆̆ında açıklamalı çeviribilim terimcesi. İstanbul: Multilingual Yabancı Dil Yayınları.

Bölükbaşı, M. (2020). "Eski Arap Dünyasının Önemli Tercümanları ve Tercümanlık Faaliyetleri”Turkish Studies-Social Sciences, 2867-2877 Volume(Issue): 15(6) 27 October/Ekim.

Bölükbaşı, M. (2020). “Arap Dünyasında Tercüme Faaliyetleri”- Turkish Studies-Social Sciences, 10051015 Volume(Issue): 15(3) 30 April/Nisan.

Bölükbaşı, M. (2021). Beytu'l-Hikme'nin Kuruluşu, Önemli Mütercimleri ve Çeviri Faaliyetlerine Katkısı. (Ed.) Kurt,G. Işık, R. Filoloji Alanında Araştırma ve Değerlendirmeler. Ankara: Gece Kitaplı̆̆l.

Bölükbaşı, M. (2021). Batı Dünyasında Yapılan İlk Kur'ân-ı Kerîm Çevirileri. Social Sciences Research Journal, 10 (3), 558-563.

el-Câhız, Kitâbu'l-Hayevân, I-VII, (nşr. 'Abdusselâm Muhammed Hârûn), Kahire 1938, I, 76-78; Sarıkaya, M. "el-Câhız'dan Es-Safedî’ye Çeviri Teorisi", Bilimname 2003 / 3 (Eylül 2003).

Dickins, J., Hervey, S. ve Higgins, I. (2017). Thinking Arabic Translation. A Course in Translation Method: Arabic to English (2. bs.). London and New York: Routledge,

Doğru E. (2011). Dilin Derin Devleti Deyimler, (1. bs.). Ankara: Fecr Yayınları.

Durmuş, İ. (2004) “Menfeluti, Mustafa Lutf̂”, TDV İslâm Ansiklopedisi. Ankara: C. 29.

Er, R. (2012). Çağdaş Arap Edebiyatı Seçkisi. Ankara: Vadi Yayınları.

Göktürk, A. (2016) Çeviri: Dillerin Dili (12. bs.). İstanbul: Yapı Kredi Yayınları

Gitânî, C. (1980). Necib Mahfûz Yetezekker. Beyrut: Dâru'l Meysere.

Gitânî, C. (2007). el-Meclisi'l-Mahfûziyye. Kahire: Dâ'u'ş-Şuruk.

el-Hâmisi, A. (2011), Necib Mahfûz fi Mir'atu'l İstişrak es-Sufiyye. Kahire

Haridy. M. (2017). "Arapça Türkçe çevirisinde problem olarak deyimlerin çevirisi", Uluslararası Ortadoğu Kongresi(Dil, Tarih ve Edebiyat) Bildiriler Kitabı 2.cilt. Ankara

Keşk, A. (1979). Kelimetuna fi red ala Evlâdu Hâretinâ Necib Mahfûz. Kahire: Kitabul-Muhtar

Kurt, G. (2019). Necîb Mahfûz romanlarının Arapçadan Türkçeye çevirilerinin erek odaklı çeviri kuramı ve çeviri stratejileri açısından incelenmesi, Gazi Üniversitesi Eğitim Bilimleri Enstitüsü Basılmamış Doktora Tezi, Ankara.

Köprülü, O. F. "Efendi"(1992-94), TDV İslâm Ansiklopedisi, İstanbul, cilt 10- "Bey" cilt 6.

Mahfûz, N. (1996). Hırsız ve köpekler, Çev. Rahmi Er. Konya: Vadi Yayınları.

Mahfûz, N. (1988). el-Baki mine'z-zaman sa'a. Kahire: Mektebetu'l-Masr.

Mahfûz, N. (2006). Hemsu'l-cünun. Kahire: Dâr'u'ş-Şüruk.

Mahfûz, N. (2013). Ezilenler, Çev. Volkan Atmaca. İstanbul. Kırmızı Kedi.

Mahfûz, N. (2015). Nil üzerinde gevezelik, Çev. Rahmi Er. Ankara. Hece Yayınları.

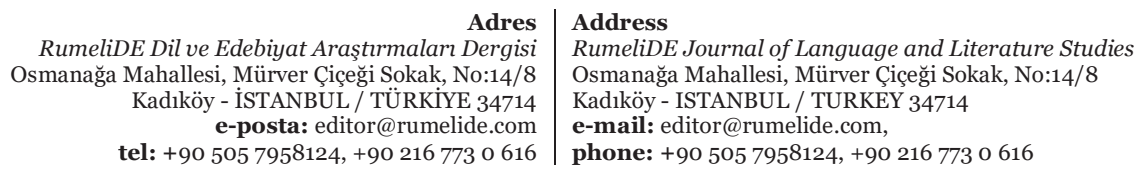


Mansûr, M. A. (2006). et-Terceme beyne’n-nazariyye ve’t-tatbîk (2. bs.). Kahire: Dâru'l- Kemâl.

Munday, J. (2001). Introducing translation studies: theories and applications. London; New York: Routledge.

Nakkaş (1995). fi Hubb Necib Mahfûz. Kahire: Dâru'ş-şuruk.

Nakkaş (1997). Safahât min muzekkirât Necib Mahfûz. Kahire: Dâru'ş-şuruk.

Newmark, P. (1988). A textbook of translation. New York - London: Shanghai Foreign Language education Press.

Nida, E. ve Taber, C. (1982). The theory and practice of translation. Leiden: E. J. Brill.

Özer, S. Ö. (2007). Osmanlı Devleti idaresinde Mısır (1839-1882), Firat Üniversitesi Sosyal Bilimler Enstitüsü, Basılmamış Doktora Tezi, Elâzı ̆̆.

Özyön, A.. (2014) “Çeviride eşdeğerlik kavramının yeniden tanımlanması ve eşdeğerlik kavramı ile ilgili sorunlar”. International Journal of Languages' Education and Teaching, 2(1) Kütahya.

Snell-H. M. (2006). The turns of translation studies: new paradigms or shifting viewpoints? Amsterdam; Philadelphia: J. Benjamins Pub.

Suçin, M. H. (2013). Öteki dilde var olmak: Arapça çeviride eşdeğerlik (2. bs.). İstanbul: Say Yayınları.

Şanverdi, H.İ. - Yıldız, M. (2019). “Azrâ’u Câkartâ Adlı Romanın Türkçe Çevirilerinin Çeviri Stratejileri Açısından İncelenmesi” - Dil ve Edebiyat Araştırmaları (DEA), Bahar.

Ürün, K. (2002). Necîb Mahfûz toplumsal gerçekçi romanları. Konya: Çizgi Yayınları.

Venuti, L. (2004). The translator's invisibility: a history of translation, London and New York.

Yazıcı, M. (2011). Çeviribilimde araştırma: disiplinlerarasılıktan disiplinlerötesiliğe. İstanbul: Multilinugal.

Yıldız, M. (2017) "Türkiye’de Necib Mahfûz literatürüne genel bir bakış", Uluslararası Ortadoğu Kongresi (Dil, Tarih ve Edebiyat), Bildiriler Kitabı II. Cilt 78-87, Ankara.

Yıldız, M. (2002). ”Necîb Mahfûz’un el-Liss ve'l-Kilab adlı romanı”, Nüsha, yıl:2, sayı:5, Bahar.

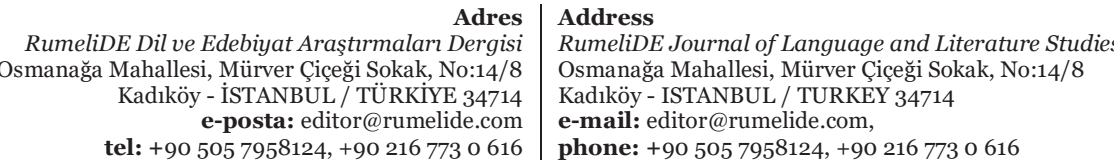

